\title{
PORPHYRIA REVISITED
}

\author{
by
}

\author{
LINDSAY C. HURST*
}

\begin{abstract}
Take her, fair son; and from her blood raise up Issue to me: that the contending kingdoms Of France and England, whose very shores look pale With envy of each other's happiness, May cease their hatred.
\end{abstract}

W. Shakespeare, King Henry V, Act V, Sc. 2.

IDA MACALPINE and Richard Hunter ${ }^{1,2,3}$ traced four descendants of the Houses of Hanover and Hohenzollern with biochemical evidence of variegate porphyria. They produced a wealth of convincing evidence that the disease afflicted numerous members of these Houses, stretching back from Queen Victoria's father Edward Duke of Kent and Frederick the Great to Margaret Douglas, Countess of Lennox (1515-1578) and James $V$ of Scotland (1512-1542). These latter shared the same mother, Margaret Tudor (1489-1541), who married twice. Previously there has been no suggestion that this disease - inherited as a Mendelian dominant with incomplete expression - could be traced further back. Professor G. R. Elton of Cambridge knows of no evidence that Margaret Tudor's father, King Henry VII, suffered from the effects of the disease.

Perhaps the story can be traced back to St. Crispin's Day, 25 October 1415. That day, 10,000 English under Henry V routed 60,000 French under the Constable d'Albret. As a result, in 1420, Henry V married Catherine of Valois, daughter of the French King, Charles VI (1368-1422). Jeanne de Bourbon, Charles VI's mother, lost "her good sense and memory" for a few months in 1373 when she was aged thirty-five. Her brother, Louis II de Bourbon, "died a melancholic".4

Charles VI was subject to periods of insanity. Froissart, referring to 25 March 1392, said; "After the parliament had been at Amiens, the King of France succumbed to an illness with fever and hot malaise..." (en fièvre et en chaude maladie). ${ }^{5}$ Brachet ${ }^{4}$

*Lindsay C. Hurst, M.A., F.R.C.Psych., Moorhaven Hospital, Ivybridge, Devon.

${ }^{1}$ Ida Macalpine and Richard Hunter. 'The "insanity" of King George III; a classic case of porphyria', Br. med. J., 1966, i: 65-71.

${ }^{2}$ Ida Macalpine, Richard Hunter and C. Rimington, 'Porphyria in the Royal Houses of Stuart, Hanover and Prussia. A follow-up study of George III's illness', ibid., 1968, i: 7-18.

${ }^{3}$ Ida Macalpine and Richard Hunter. George III and the mad-business, 1st ed., London, Allen Lane (Penguin Press), 1969.

4 A. Brachet, Pathologie mentale des rois de France: Louis XI et ses ascendants. Une vie humaine etudiée à travers six siècles d'hérédité, Paris, Machèble, 1903, Livre 2, pp. 72-81, 623-624.

${ }^{5}$ Jean Froissart, Chroniques, 1410, in J. B. M. C. Kervyn de Lettenhove (editor), Oeuvres ... de Froissart, Brussels, Académie Impériale et Royale, 1870 etc., vol. 14, p. 389. 


\section{C. Hurst}

stated firmly that "chaude maladie" indicated convulsions. On a blazing, hot day that August, Charles was riding muffled up in a black velvet jerkin. In the forest of Mans he was accosted by a crazy hermit who said that he had been betrayed. Emerging on to a sandy plain, one of the pages fell asleep and dropped his lance. The king drew his sword and attacked the rest of the party. No one was hurt (Froissart ${ }^{5}$ ). Another chronicle gave a gloomier account; "During this access of madness, the king killed four men; among others a famous chevalier of Gascony, called de Polignac, who was a bastard." Afterwards he was "deprived of the use of his members"6. "He talked neither to man nor woman, thus appearing more dead than alive". ${ }^{7}$ After a week, his symptoms abated, he recovered his appetite and recollection of things about him, and was horrified at what he had done. His doctor, Guillaume de Harseley, said that he had inherited his mother's weak nerves and recommended amusements and relaxations. $^{5}$

In June 1393 he relapsed. ${ }^{6}$ "He pretended that he was not married and had never had children; he forgot likewise his own person and his title of King of France, maintaining that he was not called Charles and did not have the Fleurs de Lis as arms. When he saw his arms or those of his wife engraved on his gold plate or elsewhere, he furiously effaced them." Relapses and remissions occurred until his death in 1422 . One time he complained of terrible pain. ${ }^{8}$ Enea Silvio de' Piccolomini: "He sometimes believed that he was glass and could not be touched, he inserted iron rods in his clothes, and in many ways protected himself lest he broke in falling".9 The autopsy, however, showed a clear liver. ${ }^{10}$

His son (1403-1461) - endearingly called the Dolphin by Holinshead and perhaps in reality his brother's son - succeeded as Charles VII. At the age of nineteen, late in 1422 , he changed from active confidence to apathetic lethargy, allowing his favourites to be killed without protest. Bishop Juvenal"1 spoke of the sleep of death ("somno sepultus"). In the decade following the arrival of Joan of Arc (1429), he was completely relieved. His death at the age of fifty-eight was probably in a delirious state due to a dental abscess. 4

The son of Henry V and Catherine of Valois was King Henry VI of England (1421-1471). Clarke ${ }^{12}$ makes much of his mildness, lack of drive, piety, and prudery, and calls him schizoid, but this seems unwarranted. Following the defeat of Castillon on 17 July 1453, when Talbot was killed and the English lost Bordeaux, the king suffered fifteen months of insanity. He was thirty-one at the time. "But after he had reached Clarendon about the feast day of St. Thomas the martyr, he fell, through a

\footnotetext{
' Chronique du Religieux de Saint-Denys: la règne de Charles VI de 1380 à 1422, edited by M. L. Bellaguet, Paris, 1839, vol. 2, pp. 19,87.

'Address of Jean Petit, edited by L. Douet-d'Arcq, Choix de pièces inédites relatives au règne de Charles VI, Paris, 1863, vol. 1, p. 227.

B. Michelet, The history of France, translated by W. K. Kelly, London, Chapman \& Hall, 1846, vol. 2, pp. $315,316$.

9 Pii II, Commentarii rerum memorabilium quae temporibus suis contigerunt, 1584, p. 164.

${ }^{10}$ Chron. Anonyme de Douet, Monstrelet, vol. 6, p. 324.

"Bishop Juvénal, MS. fr. 5022, fol. 5-6 (Beaucourt, vol. 3, 137).

12 B. Clarke, Mental disorder in earlier Britain. Exploratory studies, Cardiff, University of Wales Press, 1975, pp. 196-199.
} 


\section{HOUSES OF VALOIS, LANCASTER, TUDOR AND STUART}

$\square$ TRANSMITTERS
$\square$ POSSIBLE TRANSMITTERS $\triangle$ INSANE

CLINICAL EVIDENCE OF PORPHYRIA.

$\triangle$ CLINICAL EVIDENCE + DISCOLOURED URINE

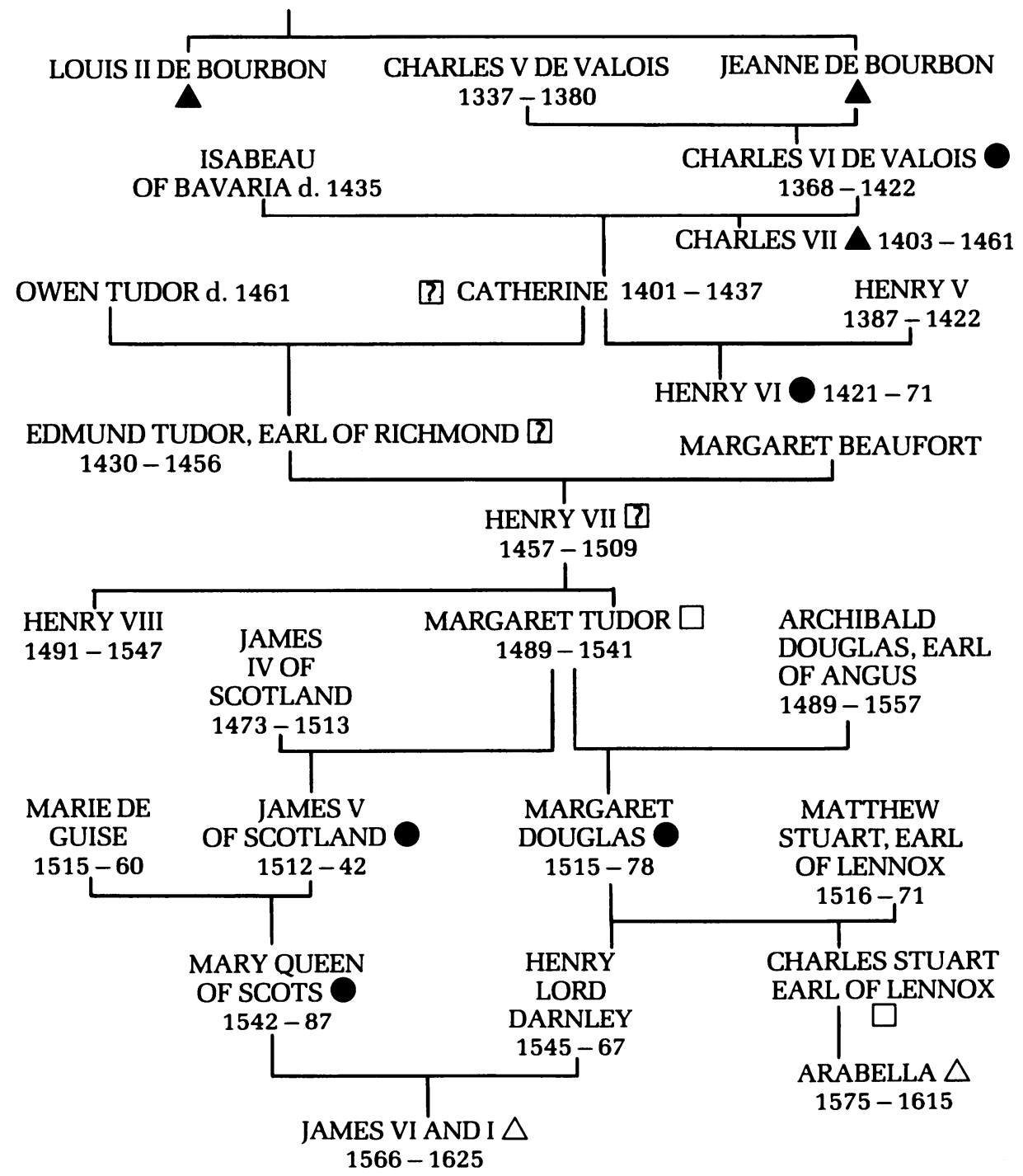




\section{C. Hurst}

sudden and unexpected fright, into such an illness that for a full year and a half he was without natural sense or intelligence adequate to administer the government. No doctor or medicine had power to cure that illness" ${ }^{13}$ The fright is nowhere explained.

Abbot Whethamstede14 described the symptoms: "Then by our Lord the King falling into such a distemper and infirmity that he lost his sense of time and memory and also lost the use of his limbs, so that he could not proceed on his feet, nor lift up his head, nor readily move from the place in which he sat". John Stodeley wrote on 19 January $1454^{15}$ that he took no notice of his baby son - "they departed thens without any answere or countenaunce savying only that ones he loked on the Prince and caste doune his eyen agen, without any more". Richard of York established himself as Protector. Finally, the king recovered. According to the Paston Letters, ${ }^{16}$ he said he "never knew til that tyme, nor wist no what was seid to him, nor wist not where he had be whils he hath be seke, til now". On 28 October 1455, John Gresham wrote to John Paston: "... so much rumor is here; what it menyth I wot not, God turne it ... at Hertford, and summe men ar a ferd that he is seek agyen". Subsequently, he saw visions and on one occasion heard an hallucinatory voice. ${ }^{17}$

Henry V, "too famous to live long", died in 1422. His widow Catherine married a commoner - Owen Tudor - and thus became the grandmother of King Henry VII.

These facts are suggestive. Insanity involved four members of the Royal House of Valois in three successive generations. Charles VI had convulsions at the age of twenty-three, followed a few months later by a confusional illness in which he killed four people and then lost the use of his limbs. Homicide has been reported in acute porphyria. ${ }^{18}$ To the end of his life he suffered psychotic relapses. However, it appears that his liver was unaffected. Charles VI's daughter became the mother of Henry VI of England, who had a prolonged confusional illness when aged thirty-one, during which he lost the use of his limbs. There may have been further illnesses. Catherine de Valois was also the great grandmother of Margaret Tudor, mother in her turn of two porphyria sufferers who started the story so skilfully traced by Macalpine and Hunter. ${ }^{1,2,3}$

\section{SUMMARY AND CONCLUSIONS}

Macalpine and Hunter have detected four descendants of the Royal Houses of Hanover and Hohenzollern with biochemical evidence of variegate porphyria. They traced clinical evidence back from Edward Duke of Kent and Frederick the Great, converging on Margaret Tudor, sister of Henry VIII. The suggestion is made here that the condition might be traced back further to Henry VI of England and Charles VI of France in the fourteenth and fifteenth centuries.

${ }^{13}$ J. A. Giles, Incertt auctoris Chronicon Angliae, London, Caxton Society, 1848.

${ }^{14} \mathrm{H}$. T. Riley (editor) Chronica monasterii S. Albani; Registrum Abbatiae Johannis Whethamstede I, London, 1872.

${ }^{15}$ Newsletter of John Stodeley, 19 January 1454. British Library, Egerton MS. 914.

${ }^{16}$ The Paston Letters. 1422 to 1509 A.D., edited by James Gairdner, Birmingham: Public Record Office, 1872 , vol. 1, letters $226,352$.

17 M. R. James (editor), Henry the Sixth (J. Blacman's memoir), Cambridge University Press, 1919.

${ }^{18}$ P. A. Trafford, 'Homicide in acute porphyria', Forensic Science, 1976, 7: 113-120. 